Peer-Reviewed Article

ISSN: 2162-3104 Print/ ISSN: 2166-3750 Online

Volume 5, Issue 4 (2015), pp. 512-525

(C) Journal of International Students

http://jistudents.org/

\title{
Are International Students Cash Cows? Examining the Relationship Between New International Undergraduate Enrollments and Institutional Revenue at Public Colleges and Universities in the US
}

\author{
Brendan Cantwell, $\mathrm{PhD}$ \\ Michigan State University (USA)
}

\begin{abstract}
There has been growing interest in the business of international education. It is often assumed that universities seek international students as a means of generating revenue. The broad purpose of this study was to understand the effects of increased international student enrollment on net tuition revenue. Informed by resource dependency and academic capitalism theory, this study used panel regression techniques to estimate the effect of enrolling an international undergraduate student on tuition revenue among public colleges and universities in the United States Findings show some but not all institutions are able to generate additional income by enrolling additional international students.
\end{abstract}

Keywords: international students, resource dependence, academic capitalism, regression

$\mathbf{U}_{\text {ser, }}$ or tuition, fees have been on the rise in higher education systems around the world. Fees have recently been increased in many countries and newly implemented in a number of systems where students previously did not pay tuition. In some countries, such as the United Kingdom (UK), fee increases reflect explicit government policy while in others, like the United States (US), higher education institutions (HEIs) have increased fees without explicit changes in government policy designed to increase fees. In both cases, fees have been charged in order to share the cost of providing higher education between the state and the students (and their families) who consume education (Johnstone, 2004; Johnstone \& Marcucci, 2010). However, some fee schemes have extended beyond cost sharing. HEIs, especially in Anglo-Saxon countries, have become increasingly entrepreneurial and seek revenue through market-like competition (Bok, 2003; Clark, 1998; Marginson \& Considine, 2000; Morphew \& Eckel, 2009; Slaughter \& Cantwell, 2012; Slaughter \& Leslie, 1997). Competition for fee-paying students has been one prominent way in which HEIs compete for additional income (Brown, 2010; McBurnie \& Ziguras, 2003; Marginson, 2007; Slaughter \& Cantwell, 2012).

Internationally mobile students constitute a large group of potential fee- paying students. The international student market has been large and growing, with over 4 million students now 
studying outside of their home country (see Organisation for Economic Cooperation and Development [OECD], 2013, p. 306). International students, especially those at the undergraduate level, have been especially attractive as a source of revenue. International undergraduate students have sometimes been charged fees by countries where there are no fees for national students, such as in Sweden. In countries where domestic students share some of the costs but also enjoy a state subsidy, international students have often been charged fee premiums (Johnstone \& Marcucci, 2010, pp. 119-120), such as in the UK and Australia. Indeed, HEIs in some Anglophone countries, especially Australia and the UK, have leveraged international student fees as a means of financing their operations (Ziguras, 2011). For example, Australia positioned itself as a major exporter of education and some Australian HEIs collect nearly onequarter of their total revenue from overseas student fees (Marginson, 2007). Even in Finland, which has a strong egalitarian tradition and expectation for the social provision of higher education, HEIs now have the option of charging fees to non-European Union (EU) students in some programs (Kauppinen \& Kaidesoja, 2014). While cost sharing has undoubtedly been a consideration, the implementation of oversees tuition fees has also been part of general policy shift in many countries towards a more market based and entrepreneurial higher education system (Slaughter \& Cantwell, 2012).

A number of countries including China (McCafferty, 2013), France (Marshall, 2013), Japan (Shao, 2012), and the United Kingdom (UK) (Buchanan, 2013) have recently announced plans to attract more international students at the undergraduate level. Although rationales for attracting more international students vary, the potential for economic gain is a common, although not universal, motivation (Lee, Maldonado-Maldonado, \& Rhoades, 2006). As cost sharing schemes have become more extensive, and as universities have become more enterprising, the impulse to attract international undergraduate students in order to generate revenue may have increased in many countries. Both the popular press and academic literature has been replete with accounts of how individual HEIs or national systems have generated income through international student recruitment. However, there has been little systemic research into the relationship between enrolling additional international students and institutional revenue. To put it another way, it has been unclear how much additional revenue HEIs stand to gain on average by recruiting additional international students.

The broad purpose of this study was to understand the effects of increased international student enrollment on net tuition revenue. Net tuition revenue is the total amount of money a HEI collects in study fees, minus any scholarships, grants, tuition discounts, or stipends an HEI offers to students. Net tuition revenue is the income a HEI generates from tuition that can use to support its operations. Because there is great heterogeneity in the way higher education is financed and because there are not good nationally comparable higher education enrollment and financial data, this study aimed to provide some insight into the relationship between enrolling fee-paying international students through a single-country analysis. Using panel regression techniques, the effect of enrolling an international undergraduate student on net tuition revenue among public colleges and universities in the United States (US) is estimated. While the findings of this study cannot be applied to other national contexts the implications are situated in the broader international environment in which many more students are crossing borders and in which HEIs seek additional revenue from students and other sources. A goal of this study was to determine if public institutions, on average, have been generating net tuition revenue by enrolling additional international students. Further, the study sought to identify which types of intuitions have seen net revenue increases and how much the average gain has been. 


\section{Literature Review}

International education has come to be understood as an export industry (Ziguras, 2011). Understanding international education as an export industry brings national economies into focus. For example, the Institute for International Education (IIE, 2014) calculated that international students added over $\$ 27$ billion to the US economy over the 2013/2014 academic year. Others have made the more general argument that in addition to direct tuition payments international students bring skills and creativity that contribute to innovation and economic growth (Florida, 2007; Tremblay, 2005). Although research into national-level economic contributions of international students has been frequently cited, this work has said relatively little about the effect of enrolling international students on HEI finances. This is to say, while organizations like the IIE have demonstrated the aggregate financial benefits of international students in the US, research has not established the expected return associated with enrolling international students for individual HEIs in the US. HEIs in several countries, perhaps most notably Australia and the UK, have positioned themselves as providers of cross- border education and seek to derive revenue from enrolling students from abroad (Marginson, 2007). Competition in international education markets has recently been seen by HEIs and governments as a strategy not only to promote national economic interests but also to boost HEI balance sheets (Douglass \& Edelstein, 2009; Slaughter \& Cantwell, 2012).

During the 2013-2014 academic year, US colleges and universities enrolled over 886,000 international students, which accounted for approximately $4 \%$ of all tertiary enrollments in the country. The majority (65\%) of all international students in the US were self-financed. Top countries of origin included China, India, South Korea, Saudi Arabia, and Canada. International students were enrolled in all institutional types but these students tended to congregate in large and well-known universities. Six of the top ten institutions in terms of international student enrollments were large public research universities. Approximately $50 \%$ of all international students were enrolled in business and management, engineering, or math and computer science programs. Degree seeking undergraduate students made up approximately one-third of all international students enrolled at HEIs in the US (IIE, 2014). Of particular note was the trend towards increased enrollment of international undergraduate students. The number of international undergraduate students enrolled at US HEIs increased by 55\% from 2004/5 to 2013/4 academic years (IIE, 2014).

Observers of international education noted that the trend of growing international undergraduate enrollments in the US appeared especially prominent at public HEIs (e.g., Choudaha, 2011). Anecdotal evidence supported this observation. Take for example the University of Illinois at Urbana-Champaign (UI). In September 2006, UI enrolled 350 new international undergraduate students, accounting for $4.9 \%$ of all new undergraduate enrollments (University of Illinois, 2012). By September, 2012 UI enrolled 910 new international undergraduates, totaling $13.1 \%$ of all new undergraduate enrollments (University of Illinois, 2012).

What accounted for the recent increase in international undergraduate students at public colleges and universities in the US? Overall expansion of international student mobility was one possible explanation. Another plausible explanation was that international undergraduate students were sought by HEIs because they yielded income from tuition fees. The need to generate additional revenue from tuition was especially keen at public HEIs because public funding had declined considerably in recent years (Ehrenberg, 2012). As public HEIs became

September/October $2015 \quad$ http://jistudents.org $\quad$ Volume $5 \bullet$ Issue 4


more dependent on tuition revenues, they have turned to full-fee paying students to generate revenue (Desrochers, Lenihan, \& Wellman, 2010; Heller, 2011). Undergraduate students have been attractive targets in the pursuit of tuition revenue because they nearly all pay tuition. Hence, public HEIs in the US may have sought to enroll additional international undergraduate students in order to generate additional revenue.

The claim that US colleges and universities have enrolled more international undergraduate students in order generate additional revenue has been gaining popular traction. Recent news reports asserted that public colleges and universities recruited international students in order to replace income lost by state budget cuts (Choudaha, 2011; Fischer, 2011; Lewin, 2012). These stories suggested that financial interests drove the decision to enroll more international students. As Reisberg (2012) from Boston College's Center for International Higher Education explained, efforts to recruit international students felt " ... a lot like a business transaction with the expectation of a good ROI (return on investment) ..." (para., 3). The idea that international student revenues were used to fund university activities was consistent both with the expansion of cost- sharing schemes and with the rise of entrepreneurism and marketization among colleges and universities. While anecdotal evidence supported claims that HEIs were cashing in on international student markets such claims had not been investigated systematically.

\section{Theoretical Framework}

Cost sharing helped to explain how fees could be used to control public expenditures by sharing the costs of provision with those who participate in higher education. However, cost sharing concepts have been best used to understand policy and have not been best suited to explain individual HEI behavior and finances. Hence, this study drew from theory that was developed to explain organizational behavior. The logic used to claim US public HEIs seek international undergraduate students was formalized utilizing resource dependence and academic capitalism theories.

Resource dependence theory indicates that organizational structure and behavior reflects the resource environment (Pfeffer \& Salancik, 1978). In other words, when organizations are dependent upon resources derived externally, organizational form and activities become consistent with the demands of the resource environment. When the resource environment changes, HEIs have adapted to fit the new environment (Tolbert, 1985), although some institutions have been able to respond more effectively than have others (Taylor, Cantwell, \& Slaughter, 2013). Public colleges and universities in the United States face a long-term trend of reduced state appropriations as a share of their total operating expenses. This trend was exacerbated by the recent recession (Ehrenberg, 2012). As state appropriations decline, public colleges and universities have become more dependent on revenue from out-of-state students (Jaquette \& Curs, 2015). Similarly, and following resource dependence theory, it is likely that public colleges and universities become dependent upon revenue derived from international student enrollment as state appropriations decline.

Academic capitalism shares resource dependence theory's focus on the resource environment but highlights endemic marketization. The theory of academic capitalism assumed that HEIs responded to globalization and neoliberal policy regimes by becoming more entrepreneurial, and competing intensely for resources and market shares (Slaughter \& Cantwell, 2012). Academic capitalism indicated that HEIs had become increasingly market- oriented organizations that aggressively competed for income. HEIs have competed for income in part to 
secure market-based resources in the face of declining public support (Slaughter \& Leslie, 1997) and, in part because they have increasingly adopted the norms of business firms and view students as customers (Slaughter \& Rhoades, 2004). Academic capitalism theory predicts that HEIs are likely to increasingly view international students as fee-paying customers and seek to aggressively compete for revenue from these students (Lee, Maldonado-Maldonado, \& Rhoades, 2006; Slaughter \& Cantwell, 2012). This is to say that academic capitalism theory predicts HEIs will seek to generate revenue from international students even when all other financial conditions are constant.

\section{Research Method}

This study assessed the relationship between international student enrollment and revenue at public HEIs in the US. Therefore the sample was limited to public (four-year) colleges and universities that award at least bachelor degrees. The Carnegie Foundation for the Advancement of Teaching (CFAT) provided a basic classification scheme that categorizes HEIs based on their programmatic offerings and research activity. Categories relevant to this study included "research universities," "doctoral universities," "master's colleges and universities," and "baccalaureate [bachelor] colleges" (CFAT, 2012).

Two separate analyses were conducted - one for research and doctoral universities, and one for master's and baccalaureate colleges. Three considerations underpinned the decision to separate research and doctoral universities from bachelor and master's granting HEIs. First, the missions of these different institutional types made direct comparison problematic. Second, these institutions were differentially resourced. Research and doctoral universities, on average, charged higher tuition and enjoyed higher per-student state appropriations than did bachelor and master's colleges, whereas tuition income accounted for a higher share of all revenue at master's and bachelor institutions (Wellman, Desroches, \& Lenihan, 2008). Third, research and doctoral universities tended to enroll greater numbers of international students than did bachelor and master's colleges (IIE, 2012b).

There were 177 public research and doctoral universities in the US (CFAT, 2012). The sample included 151 of these universities, or $88 \%$ of the population. There were 405 bachelor and master's colleges in the US (CFAT, 2012). The sample included 329 of these institutions, or $81 \%$ of the population. The sample is somewhat smaller than the population because there was not $100 \%$ data coverage for all variables and HEIs missing data for one or more variable were dropped from the analysis.

\section{Data}

The data analyzed covered the period 2000 through 2009. During this period, the number of international undergraduate students enrolled at US public institutions had increased substantially (IIE, 2014). Data were drawn from two sources. Most variables were collected from the Delta Project on Postsecondary Education Costs, Productivity, and Accountability. This source standardizes finance, enrollment, and other figures collected annually by the National Center for Education Statistics (NCES). The number of newly enrolled international undergraduate students was collected from NCES's Integrated Postsecondary Education Data System (IPEDS). Since the year 2000, IPEDS has annually collected the number of new international students enrolled by all colleges and universities in the US.

IPEDS data were used, as opposed to other well-known sources (e.g, OECD, IIE), for two reasons. First, IPEDS disaggregated data by institution, academic level, and enrollment 
status (first-time enrollments), which facilitated institutional-level panel analysis. Second, IPEDS data offered the additional advantage of being gathered using the same process and definitions as the other variables used in the analysis.

Analysis concluded at the academic year ending in 2009 because this the most recent year for which all data were available. All financial variables were held in constant 2009 US dollars. Count (such as the number of students) and financial variables are log-transformed. Count variables were logged under the assumption that the return on enrolling an additional student is non-linear. In other words, adding an additional student if an institution enrolled 1,000 students is different from adding an additional student if an institution enrolled 10,000 students. Similarly, financial variables were logged because it was assumed colleges and universities spent their first dollar differently than they spent their last dollar.

\section{Analytic Strategy}

This study investigated the relationship between new international undergraduate enrollments and institutional revenue. In testing this relationship, logged net revenue, derived from student paid tuition and fees, was set as the dependent variable. The logged count of new international students enrolled at the undergraduate level was the independent variable of interest. Following resource dependence theory that predicts that revenue generated from international students, will be sought to preplace state funding, state appropriations are included in the model. Following academic capitalism that predicts HEIs will increasing compete for revenue derived from international students (as well as other sources), a log-linear time trend is included in order to control for increased revenue seeking behavior during the period of study. Several control variables, including counts of student enrollment (graduate and undergraduate) and faculty members, were also included.

Analysis was conducted using linear regression with time-series cross- sectional, or panel, data. The dataset includes multiple observations of a single unit over time. In such datasets, variation resides both within a particular unit (observed over time) and between multiple units (observed at the same point in time). This analysis focused on the variation within units (HEIs) because it is the individual HEI that enrolls a student that stands to enjoy the fee revenue derived from that student. Fixed effects estimates, as opposed to random effects estimates, were used in the regression model. Fixed effects estimates consider only within-HEI variance, and minimize bias in coefficient estimates by providing an arithmetic control for timeinvariant unobserved university-level characteristics (Zhang, 2010).

Fixed institutional-level effects do not vary over time. Therefore, institution- level characteristics that are time-invariant, such as geographic location, were not included in the models. Because the fixed effects controlled for all between- university variance, estimated coefficients could be interpreted as predicted changes at a particular institution. Although fixed institutional-level effects provide robust control for time-invariant characteristics and variation between units, it was important to include additional controls for characteristics of HEIs that did vary over time.

All undergraduate students typically pay tuition at US colleges and universities. At public institutions, in-state students tend to pay lower tuition fees than out-of-state students pay. Therefore the log count of all in-state and out-of- state undergraduate students was included. While many graduate students are supported by grants, fellowships, and teaching assistantships (Stephan, 2012), some graduate students did pay tuition fees. Therefore the logged count of graduate students was added as a control in the research and doctoral university model. This variable was omitted from the bachelor and master's institutions because these institutions 
enrolled relatively few graduate students and because preliminary analysis showed that inclusion did not improve model fit but did result in the loss of observations.

HEIs in the United States use institutional scholarships and grants as a means of persuading students to attend their institutions. Use of institutional scholarships and grants to drive enrollment is known as tuition discounting (McPherson \& Schapiro, 1998). Therefore the $\log$ of total institutional scholarships and grants was included as a control. The model also controlled for institutional size by including the log count of faculty members employed. Because public institutions enjoy state support the model for the log of state appropriations. International student enrollments are part of broader internationalization processes that has likely increased over time (Altbach \& Knight, 2007). Indeed, IIE (2014) data showed increased enrollment of international students at HEIs in the United States nearly every year during the study period. Therefore, a log-linear time trend was included to account for change over time, which is also theoretically important because academic capitalism theory predicts that HEIs will increasingly engage in revenue generating activities (Slaughter \& Rhoades, 2004). Research has shown that international students chose HEIs abroad at least in part based on rankings and reputation for academic quality (Lee, 2008). However, HEIs ranking scores were not including in the model because this study did seek to predict international undergraduate student enrollment but rather the effect of enrollment on net tuition revenue. Additionally, because ranking positions change very little (Bowman \& Bastedo, 2011), these variables are virtually time-invariant and therefore not appropriate for inclusion in a model that employs fixed effects. Finally, as a safeguard to ensure the reliability of the estimates standard errors were clustered by HEI.

It is worth offering a note on how to interpret the results of the regression models. Because logarithmic transformations were used, coefficients could be interpreted as elasticities. In other words, estimated coefficients represented the predicted percentage increase in the dependent characteristic of a particular institution, net of other variables, for a $1 \%$ increase in an independent characteristic at that institution.

\section{Limitations}

There were important limitations related to the sample and temporal frame included in this study. First, the period of study ended in 2009. If institutions substantially increased their efforts to recruit international undergraduates as sources of revenue following the 2008 financial crisis, the full extent of these activities may not have appeared in the findings. Second, this study focused on public colleges and universities in the United States. As such, the findings could not be extended to all US higher education institutions but are instead limited to the public four-year sector. Third, the tuition pricing system in the US is difficult to extrapolate to other national contexts. Higher education financing in the US has been distinguished by cost sharing at high levels (Johnstone, 2004), hierarchical differentiation among institutions (Slaughter \& Cantwell, 2012), and individual- level tuition discounting (McPherson \& Schapiro, 1998).

\section{Results}

Table 1 presents descriptive statistics for all variables in the years 2000 and 2009. The first column reports sampled research and doctoral universities and the second columns reports sampled bachelor and master's institutions. Mean values are reported for each variable, followed by median values, and standard deviations. Table 1 shows considerable differences between mean and median values, as well as large standard deviations for most of the selected variables. 
Table 1: Descriptive Statistics

\begin{tabular}{|c|c|c|c|c|c|c|}
\hline \multirow[b]{2}{*}{ Variable } & \multicolumn{3}{|c|}{$\begin{array}{l}\text { Research and Doctoral Universities } \\
\qquad(\mathrm{N}=151)\end{array}$} & \multicolumn{3}{|c|}{$\begin{array}{l}\text { Bac. and Master's Institutions } \\
\qquad(\mathrm{N}=329)\end{array}$} \\
\hline & Mean & Median & SD & Mean & Median & SD \\
\hline New International Undergraduates & 59.5 & 32.0 & 76.7 & 20.9 & 9.0 & 41.8 \\
\hline Net Tuition Revenue, '000 US\$ & 85896.8 & 57745.2 & 87051.0 & 4918.9 & 1011.0 & 12284.3 \\
\hline Institutional Tuition Grants, '000 US\$ & 7600.1 & 3497.7 & 13400.0 & 1227.1 & 5170.3 & 2073.9 \\
\hline State Appropriations, ' 000 US\$ & 146147.7 & 102909.0 & 155367.3 & 16120.4 & 7669.8 & 32919.5 \\
\hline In-State Undergraduate Cohort & 1464.9 & 1036.0 & 1853.9 & 230.8 & 355.6 & 776.9 \\
\hline Out-of-State Undergraduate Cohort & 338.2 & 117.0 & 542.5 & 32.2 & 0.0 & 102.4 \\
\hline Total Graduate Student Enrollment & 3031.5 & 1397.0 & 2037.7 & $\mathrm{~N} / \mathrm{A}$ & N/A & N/A \\
\hline New International Undergraduates & 91.8 & 48.0 & 120.3 & 10006.0 & 2158.1 & 23419.0 \\
\hline Net Tuition Revenue, '000 US\$ & 182678.8 & 131316.4 & 205120.0 & 21.6 & 10.0 & 47.9 \\
\hline Institutional Tuition Grants, '000 US\$ & 176000.0 & 7270.5 & 28000.0 & 2221.9 & 9107.4 & 4191.4 \\
\hline State Appropriations, '000 US\$ & 186018.5 & 137463.3 & 203482.7 & 23055.2 & 11552.3 & 49233.7 \\
\hline In-State Undergraduate Cohort & 2974.4 & 2657.0 & 2325.6 & 1110.5 & 845.0 & 1839.4 \\
\hline Out-of-State Undergraduate Cohort & 719.7 & 456.0 & 728.9 & 138.9 & 75.0 & 189.1 \\
\hline Total Graduate Student Enrollment & 3087.8 & 1987.0 & 4709.8 & $\mathrm{~N} / \mathrm{A}$ & $\mathrm{N} / \mathrm{A}$ & N/A \\
\hline
\end{tabular}

These observations indicated that these variables were widely distributed. In such cases, median values may offer a more accurate indication of the central tendency within the distribution.

Median net tuition fees and state appropriations increased between 2000 and 2009 at both institutional types. At research and doctoral universities median net tuition revenue rose from approximately $\$ 58$ million dollars in 2000 to approximately $\$ 131$ million in 2009 . At bachelor and master's institutions median net tuition revenue rose from approximately $\$ 10$ million to approximately $\$ 22$ million over the same period. Similarly, from 2000 to 2009 median state appropriations increased from approximately $\$ 103$ million to approximately $\$ 137$ million at research and doctoral universities, and from approximately $\$ 77$ million to approximately $\$ 116$ million at bachelor and master's institutions. The median number of new international students enrolled increased from 32 to 48 at research and doctoral universities during the study period, but ticked up only slightly from 9 to 10 at bachelor and master's institutions.

\section{Figure 1. Average number of new international students}

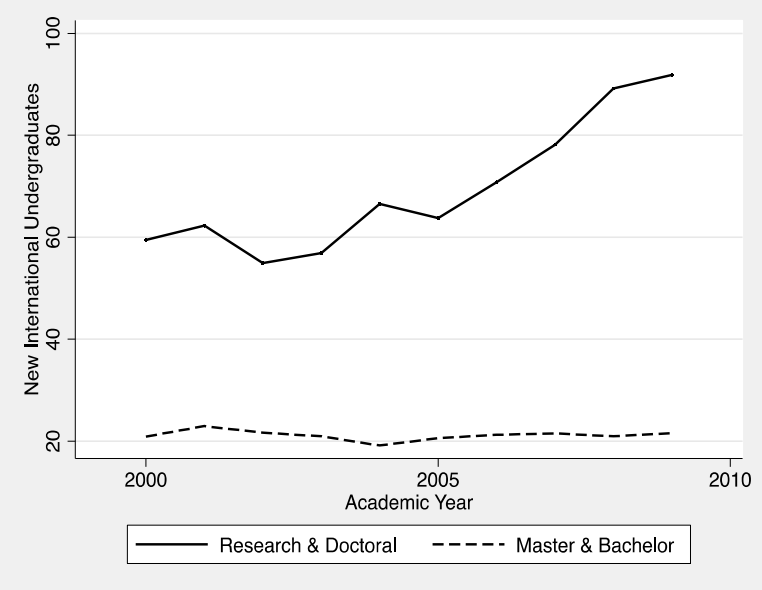

Figure 1 shows change in the average (mean) number of new international students enrolled at sampled research and doctoral universities and bachelor and master's institutions. On average, research and doctoral universities witnessed a modest decline in the number of new international undergraduate enrollments after 2001 but experienced robust growth thereafter. The average number of new international undergraduate enrollments remained flat over the period at bachelor and master's institutions. 
To summarize, research and doctoral universities enrolled more new international undergraduates, enjoyed greater net tuition revenue, and state appropriations than did their bachelor and master's counterparts. Moreover, the number of new international undergraduate students grew much faster at research and doctoral universities than it did at bachelor and master's institutions. These differences supported conducting separate analysis for these two groups. Large standard deviations showed there was substantial variation within subsamples, which supported regression analysis with fixed effects because this approach controlled for between unit variance.

\begin{tabular}{lcc} 
Table 2: Panel Regression Results with Fixed Effects & \multicolumn{2}{l}{ Between International Student } \\
\cline { 2 - 3 } Enrollment and Net Tuition Revenue & $\begin{array}{c}\text { Research and } \\
\text { Doctoral Model }\end{array}$ & $\begin{array}{c}\text { Bachelor and } \\
\text { Master's Model }\end{array}$ \\
\cline { 2 - 3 } & & \\
& $0.040^{* *}(0.0114)$ & $0.0109(0.019)$ \\
Log count of New International Undergraduate Students & $0.006(0.091)$ & $-0.004(0.0138)$ \\
Log of Institutional Scholarships and Grants & $-0.034(0.0411)$ & $0.013(0.0868)$ \\
Log of State Appropriations & $0.369^{* *}(0.1026)$ & \\
Log Count of Graduate Students & $0.0777^{*}(0.0222)$ & $0.08(0.0495)$ \\
Log Count of In-State Students & $0.053^{*}(0.0194)$ & $0.023(0.0251)$ \\
Log Count of Out-of-State Students & $0.0271(0.0634)$ & $0.3031^{*}(0.1264)$ \\
Log Count of Faculty Members & $0.332 * *(0.0119)$ & $0.370^{* *}(0.0186)$ \\
Log Linear Time Trend & 1209 & 2104 \\
Observations & 151 & 329 \\
Number of Institutions & 0.665 & 0.401 \\
R-Squared & & \\
\hline
\end{tabular}

Note. Robust standard errors in parentheses.

$* * \mathrm{p}<0.01, * \mathrm{p}<0.05$

Table 2 reports the results of fixed effects regression using panel data from 2000 to 2009 . Results for sampled research and doctoral universities are reported in the first column and results for sampled bachelor and master's institutions are reported in the second column. As predicted, there was a positive and statistically significant association between newly enrolled international undergraduate students and net tuition revenue at sampled research and doctoral universities. Holding other variables constant, a $1 \%$ increase in newly enrolled international undergraduates at a particular research or doctoral university predicted a $0.04 \%$ increase in net tuition revenue. Enrolling additional international undergraduate students yielded additional revenue when holding constant the number of all national (in-state and out-of-state) students enrolled.

Some control variables were also significant predictors of net tuition revenue at sampled doctoral and research universities. The logged count of graduate students, logged count of in-state and out-of-state domestic students, and the log-linear time trend all predicted increased net tuition revenue when holding all other variables constant. These findings were not surprising. Tuition at public colleges and universities had increased substantially over the study period, so both increased enrollments and the passage of time were likely predictors of net tuition review. A reader may be surprised to notice smaller beta coefficients for international and out-of-state students than for in-state students. The surprise comes from the fact that international and out-ofstate students tend to pay higher tuition than do in-state students. However, is important to September/October 2015 http://jistudents.org Volume $5 \bullet$ Issue 4 
remember that findings are interpreted as elasticities (see the discussion above) that estimate the predicted percentage increase in the dependent characteristic (net-tuition revenue) of a particular institution, net of other variables. At most public HEIs in-state students account for a majority of all students. Hence, a $1 \%$ increase in in-state enrollment if in-state students represents a much larger number of individual students than a $1 \%$ increase in the number of out-of-state or international students.

Only the logged count of faculty members and the passage of time predicted the log of net tuition revenue at sampled public bachelor and master's institutions. Unlike their research and doctoral counterparts, the log count of new international undergraduate enrollments did not predict logged net tuition revenue at these institutions. In other words, bachelor and master's colleges and universities did not appear to net additional tuition income from enrolling additional new international students when holding total enrollments constant. For sampled bachelor and master's institutions, no student enrollment variables predicted increased tuition revenue.

\section{Discussion and Conclusions}

This paper empirically assessed the possibility that public colleges and universities in the US generate net revenue by enrolling international undergraduate students. Findings indicated that sampled research and doctoral universities did realize net gains in tuition revenue by enrolling new international undergraduate students. Sampled bachelor and master's institutions, by contrast, did not accrue net revenue returns from enrolling additional new international undergraduate students.

Results from this study indicate that tuition paying international undergraduate students may generate additional revenue for some public universities in the US. However, the ability to generate income appears to have been limited to doctoral and research institutions. What is more, the revenue generated by enrolling additional international undergraduates is modest compared to overall tuition revenue. One might add that there is considerable heterogeneity among the research and doctoral university sub-sample in terms of the number of new international students enrolled, suggesting that all universities of this type may not realize the average within unit effect. In other words, while some universities appear to be able boost revenue by enrolling international students, international students may not be cash cows for all universities in the US. It may be that only research and doctoral universities saw increased net revenue from international student enrollments because internationally mobile students seek well-known and prestigious institutions when selecting colleges and universities in the US (Lee, 2008). To put it another way, research and doctoral universities may be able to generate revenue from international student enrollment simply because relatively large numbers of students elect to attend these institutions. The finding of differential returns from participating in the international student market is consistent with research showing that some institutions are better able than others to respond to market, or quasi-market, conditions (Taylor et al., 2013). Public research and doctoral universities appear to enjoy a revenue stream from international education that is unavailable to bachelor and master's institutions.

Gains in net tuition revenue associated with enrolling additional international undergraduate students were estimated at research and doctoral universities when holding constant the number of other students enrolled. This suggests, but does not prove, public research and doctoral universities seek additional tuition revenue not just by growing enrollments, but 
also by changing the composition of their students. Findings indicate that universities may generate additional tuition revenue by shifting the composition of their student body to be more international without expanding the overall number of students enrolled. This finding is consistent with academic capitalism (Slaughter \& Rhoades, 2004), which predicts that universities will move into areas that lead to greater market return.

\section{Implications}

While it is plausible that revenue generation is one motivation behind international student recruitment, universities enroll international students for a variety of reasons. The fact that public research and doctoral universities accrue increased net tuition revenue by enrolling additional international undergraduate students does not necessary mean that revenue potential is the primary these HEIs enroll students from abroad. Previous research has demonstrated that HEIs enroll international students for a variety of reasons (Altbach \& Knight, 2007; Verbik \& Lasanowski, 2007) and the findings of this study should not be interpreted to suggest that HEIs internationalize only to generate revenue.

Moreover, policymakers and administrators should approach efforts to recruit international undergraduate students as a means of generating income cautiously. Findings from this study suggest that only HEIs that can attract large numbers of students from abroad stand to generate substantial revenue from international student fees. While it may be tempting to cash in on international education, the results of this study suggest that such efforts may not yield a large return for the many HEIs that do not have the visibility, prestige, or programmatic offerings to attract large numbers of students from aboard (Lee, 2008). It is plausible that colleges and universities that are not already well known outside of their home country may even incur net losses if their efforts to recruit international students are more costly than the income generated from tuition paid by these students. As Slaughter and Rhoades (2004) point out, efforts at academic capitalism are often financial failures. With an uncertain payoff some institutions may be wise to enter the market with caution.

To summarize, international student mobility has implications for HEIs in the US and possible implications for HEIs elsewhere. It is commonly assumed and is demonstrated by the findings of this study, there are potential financial gains for individual institutions in the US and findings from the study partly confirm this assumption. Yet, as the findings of this study also demonstrate, only some public HEIs appear to have enjoyed net revenue gains from international student enrollment. The potential for financial gain does not mean that every university that recruits students from abroad will profit.

\section{REFERENCES}

Altbach, P. G., \& Knight, J. (2007). The internationalization of higher education: Motivations and realities. Journal of Studies in International Education, 11(3-4), 290-305.

Bok, D. (2003). Universities in the marketplace: The commercialization of higher education. Princeton, NJ: Princeton University Press.

Bowman, N. A., \& Bastedo, M. N. (2011). Anchoring effects in world university rankings: exploring biases in reputation scores. Higher Education, 61(4), 431-444.

Brown, R. (Ed.). (2010). Higher education and the market. New York, NY: Routledge.

Buchanan, R. T. (2013). 100,000 more international students in the next five years, The

September/October $2015 \quad$ http://jistudents.org $\quad$ Volume $5 \bullet$ Issue 4


Independent. Retrieved from http://www.independent.co.uk/student/news/100000-moreinternational-students-in-the-next-five-years-8736696.html

CFAT. (2012). Summary tables: Basic classification. Retrieved from http://classifications.carnegiefoundation.org/summary/basic.php

Choudaha, R. (2011). GLOBAL: The future of international student mobility, University World News, 191. Retrieved from http://www.universityworldnews.com/article.php?story=20110930190559493

Clark, B. R. (1998). Creating entrepreneurial universities: Organizational pathways of transformation. New York, NY: Elsevier Science.

Desrochers, D. M., Lenihan, C. L., \& Wellman, J. V. (2010). Trends in college spending-19982008. Washington, DC: Delta Cost Project.

Douglass, J. A., \& Edelstein, R. (2009). The global competition for talent: The rapidly changing market for international students and the need for a strategic approach in the US. The University of California Center for the Study of Higher Education. Research and Occasional Paper Series (CSHE 8.09).

Ehrenberg, R. G. (2012). American higher education in transition. The Journal of Economic Perspectives, 26(1), 193-216.

Fischer, K. (2011). Colleges adapt to new kinds of students from abroad: Younger, sometimes less-experiened students require more academic and social support. The Chronicle of Higher Education. Retrieved from http://chronicle.com/article/Colleges-Educate-a-NewKind-of/127704/

Florida, R. (2007). The flight of the creative class: The new global competition for talent. New York, NY: HarperCollins.

Heller, D. E. (2011). Trends in the affordability of public colleges and universities: The contradiction of increasing prices and increasing enrollment. In D. E. Heller (Ed.), The states and public higher education policy: Affordability, access, and accountability (pp. 13-36). Baltimore, MD: The Johns Hopkins University Press.

IIE. (2012a). Open doors 2012: Report on international educational exchanges. New York: IIE.

IIE. (2012b). The economic benefits of international students to the U.S. economy academic year 2011-2012. Retrieved from http://www.iie.org/Research-andPublications/Open-Doors/Data/Special-Reports/Economic-Impact-of-InternationalStudents

Johnstone, D. B. (2004). The economics and politics of cost sharing in higher education: Comparative perspectives. Economics of Education Review, 23(4), 403-410.

Johnstone, D. B., \& Marcucci, P. N. (2010). Financing Higher Education Worldwide: Who Pays? Who Should Pay? Baltimore, MD: The Johns Hopkins University Press.

Kauppinen, I., \& Kaidesoja, T. (2014). A shift towards academic capitalism in Finland. Higher Education Policy, 27, 23-41.

Knight, J. (2003). GATS, trade and higher education: Perspective 2003-where are we?. London, England: The Observatory on Borderless Higher Education.Lee, J. J. (2008). Beyond borders: International student pathways to the United States. Journal of Studies in International Education, 12, 308-327.

Lee, J. J., Maldonado-Maldonado, A., \& Rhoades, G. (2006). The political economy of international student flows: Patterns, ideas, and propositions. Higher Education: Handbook of Theory and Practice, 21, 545-590. 
Lewin, T. (2012). Taking more seats on campus, foreigners also pay the freight. The New York Times. Retrieved from http://www.nytimes.com/2012/02/05/education/internationalstudents-pay-top-dollar-at-us-colleges.html?pagewanted=alland_r $=0$

Marginson, S. (2007). Global position and position taking: The case of Australia. Journal of Studies in International Education, 11(1), 5-32.

Marginson, S., \& Considine, M. (2000). The enterprise university: Power, governance and reinvention in Australia. Cambridge, England: Cambridge University Press.

Marshall, J. (2013). Reforms aim to attract more foreign PhD students. University World News, No. 272. Retrieved from http://www.universityworldnews.com/article.php?story=20130517105000290

McBurnie, G., \& Ziguras, C. (2003). Remaking the world in our own image: Australia's efforts to liberalise trade in education services. Australian Journal of Education, 47, 217-234.

McCafferty, G. (2013, May 29). China in soft power push with foreign students. CNN. Retrieved from http://www.cnn.com/2013/05/29/world/asia/china-soft-power-foreign-students

McPherson, M. S. \& Schapiro, M. O. (1998). The student aid game: Meeting need and rewarding talent in American higher education. Princeton, NJ: PUP.

Morphew, C. C., \& Eckel, P. D. (Eds.). (2009). Privatizing the public university: Perspectives from across the academy. Baltimore, MD: The Johns Hopkins University Press.

OECD. (2013). Education at a glance, 2012. Paris, France: OECD.

Patton, G. (2012, September). Universities 'using foreign students as cash cows'. The Telegraph. Retrieved from http://www.telegraph.co.uk/education/universityeducation/9556080/Universities-usingforeign-students-as-cash-cows.html

Pfeffer, J., \& Salancik, G. R. (1978). The external control of organizations: A resource dependence perspective. New York, NY: Harper and Roe.

Reisberg, L. (2012, July). Why do we want international students? Inside Higher Ed. Retrieved from http://www.insidehighered.com/blogs/world-view/why-do-we-want-internationalstudents

Shao, C-F. (2012, July). Japanese polices and international students in Japan. Retrieved from http://artsonline.monash.edu.au/mai/files/2012/07/chunfenshao.pdf

Slaughter, S., \& Cantwell, B. (2012). Transatlantic moves to the market: The United States and the European Union. Higher Education, 63, 583-606.

Slaughter, S., \& Leslie, L. L. (1997). Academic capitalism: Politics, policies, and the entrepreneurial university. Baltimore, MD: The Johns Hopkins University Press.

Slaughter, S., \& Rhoades, G. (2004). Academic capitalism and the new economy: Markets, state, and higher education. Baltimore, MD: Johns Hopkins University Press.

Stephan, P. (2012). How economics shapes science. Cambridge, MA: Harvard University Press.

Taylor, B. J., Cantwell, B., \& Slaughter, S. (2013). Quasi-markets in US higher education: The humanities and institutional revenues. The Journal of Higher Education, 84, 675-707.

Tolbert, P. S. (1985). Institutional environments and resource dependence: Sources of administrative structure in institutions of higher education. Administrative Science Quarterly, 30(1): 1-13.

Tremblay, K. (2005). Academic mobility and immigration. Journal of Studies in International Education, 9, 196-228.

University of Illinois. (2012). New freshman demographics. Retrieved from http://www.dmi.illinois.edu/stuenr/\#new

September/October 2015 http://jistudents.org Volume $5 \cdot$ Issue 4 
Verbik, L., \& Lasanowski, V. (2007). International student mobility: Patterns and trends. The Observatory on Borderless Higher Education: 1-48.

Wellman, J. V., Desroches, D. M., \& Lenihan, C. M. (2008). The growing imbalance: Recent trends in U.S. postsecondary education finance. Washington, DC: The Delta Cost Project.

Zhang, L. (2010). The use of panel data models in higher education policy studies. Higher Education: Handbook of Theory and Research, 25, 307-349.

Ziguras, C. (2011). Extra-national provision. In R. King, S. Marginson, \& R. Naidoo (Eds). Handbook on Globalization and Higher Education (pp. 114-128). Cheltenham: Edward Elgar.

\section{AUTHOR}

BRENDAN CANTWELL, PhD, is an assistant professor of higher education. His research addresses the political economy of higher education and often takes a comparative and international approach. Email: brendanc@msu.edu 